\title{
HIV with Hepatitis B Co-Infection: Optimizing Treatment in Resource- Limited Settings
}

\section{Edsel Maurice Tanghal Salvana1, Angela D. Salvana² and Robert A. Salata}

${ }^{1}$ Institute of Molecular Biology and Biotechnology, National Institutes of Health, University of the Philippines Manila, Pedro Gil, Ermita, Manila, Philippines 1000 ${ }^{2}$ Section of Gastroenterology, Department of Medicine, University of the Philippines College of Medicine, University of the Philippines Manila, Pedro Gil, Ermita, Manila, Philippines 1000

${ }^{3}$ Division of Infectious Diseases and HIV Medicine, Case Western Reserve University University Hospitals Case Medical Center, 11100 Euclid Avenue, Cleveland, Ohio 44106

\begin{abstract}
Hepatitis B infection is a major cause of morbidity and mortality in HIV-infected patients. While the majority of persons infected with hepatitis $B$ are found in the developing world and were infected at birth or in early childhood, most studies in HIV and HBV co-infection have been conducted in developed countries, where the main modes of transmission are either intravenous drug use or sexual transmission. The few studies that have been conducted in resource-limited settings have very few patients, and the laboratory parameters for proper evaluation of these studies are frequently incomplete. The applicability of United States and European guidelines for HBV-co-infected HIV patients in resource-limited settings (RLS) is therefore uncertain, and may be constrained by financial issues especially with regard to appropriate initiation of antiretroviral treatment. This review discusses the few studies conducted in RLS, and proposes guidelines for treatment based on the best available evidence from these studies. In addition, the effect of co-infection on disease progression, including the role of HBV genotypes and HIV subtypes and the use of hepatitis B vaccination in HIV infection is reviewed.
\end{abstract}

Keywords: HIV; Hepatitis B; Resource-limited settings; Antiretrovirals

\section{Introduction}

Hepatitis B virus (HBV) co-infection is a major contributor to morbidity and mortality in HIV-infected patients, especially in countries highly endemic for both. The treatment of HBV in HIV-coinfection in recent years has become standard as a consequence of earlier initiation of combination antiretroviral (ARV) treatment containing lamivudine, emtricitabine and/or tenofovir. Optimal treatment is partly a matter of economics since ARV recommendations for developed countries typically include a tenofovir plus lamivudine or emtricitabine backbone, while tenofovir in resource-poor countries may not be part of first-line ARV therapy due to significantly higher costs. Substantial evidence-based gaps remain, especially since most studies involving treatment of HBV/HIV co-infected patients have been conducted in resource-rich countries [1]. HBV genotypes, prevalence rates and methods of transmission of HBV are very different in resource-limited settings (RLS). HBV population prevalence rates in the resourcelimited countries are much higher than developed countries and are likely to be of different genotypes in each region [2]. While the bulk of HBV in developed countries is acquired in adolescence and adulthood through sexual contact and injection drug use, most HBV infection in the developing world is through maternal and child infection $[3,4]$. HIV with HBV co-infection is associated with poorer outcomes beyond that from either disease alone. Rates of progression to chronic hepatitis, levels of HBV viremia, and development of cirrhosis and hepatocellular carcinoma (HCC) are all higher in HIV co-infected HBV patients [1]. In addition, occult HBV viremia with loss of hepatitis B surface antigen (HBsAg) can occur more frequently with increasing immunosuppression and thus serve as a possible reservoir for continued transmission of infection [5].

The purpose of this review is to highlight major issues in the treatment of HBV in HIV-co-infected patients in RLS, especially the applicability of current treatment recommendations, evidence for which is mostly based on studies in developed countries. We review in detail the few studies done in RLS, and compare these with recently published studies. In addition, the effect of co-infection on disease progression of both HIV and HBV infection, as well as the effect of HBV genotypes on HBV disease manifestations and the use of HBV vaccination in HIV infection are discussed. While significant heterogeneity does exist between Asian and African HIV/HBV co-infection, the impact of cost-constraints for optimal treatment is a major limiting factor in the control of both epidemics, and needs to be fully explored and considered.

\section{HIV/HBV Treatment Studies in ARV-Naive in RLS}

Four studies in HBV/HIV co-infected patients in RLS are reviewed here and summarized in Table 1.

Matthews and her colleagues [6] performed a randomized, controlled trial in Thailand in HIV treatment-naive patients initiating ARVs. These were divided into three groups based on the HBV-active component of their regimen: lamivudine only, tenofovir only, and tenofovir plus lamivudine. There were $36 \mathrm{HBsAg}$ reactive patients enrolled overall, with 22 (61\%) being hepatitis B early antigen (HBeAg) positive. Follow-up time was 48 weeks. Two patients in the lamivudine arm were lost to follow-up and there was one death in the tenofovir plus lamivudine arm, but all enrolled patients were included in an

*Corresponding author: Edsel Maurice T. Salvana, Institute of Molecular Biology and Biotechnology, National Institutes of Health, University of the Philippines Manila, Pedro Gil, Ermita, Manila, Philippines 1000, Tel: +63-917-6355726; Fax: +63-2-5213250 Email: edsel.salvana@gmail.com

Received December 15, 2014; Accepted January 30, 2015; Published February 13,2015

Citation: Salvana EMT, Salvana AD, Salata RA (2015) HIV with Hepatitis B CoInfection: Optimizing Treatment in Resource-Limited Settings. J AIDS Clin Res 6 : 425. doi:10.4172/2155-6113.1000425

Copyright: (c) 2015 Salvana EMT, et al. This is an open-access article distributed under the terms of the Creative Commons Attribution License, which permits unrestricted use, distribution, and reproduction in any medium, provided the original author and source are credited. 
Citation: Salvana EMT, Salvana AD, Salata RA (2015) HIV with Hepatitis B Co-Infection: Optimizing Treatment in Resource-Limited Settings. J AIDS Clin Res 6: 425. doi:10.4172/2155-6113.1000425

Page 2 of 6

\begin{tabular}{|c|c|c|c|c|c|c|}
\hline Study/ Country & $\begin{array}{l}\text { HBV definition/ } \\
\text { genotype }\end{array}$ & $\begin{array}{l}\text { Study type, N, } \\
\text { arms }\end{array}$ & $\begin{array}{l}\text { HIV treatment } \\
\text { status }\end{array}$ & Followup & Outcomes & Remarks \\
\hline $\begin{array}{l}\text { Matthews et } \\
\text { al., } 2008 \text { [6] } \\
\text { Thailand }\end{array}$ & $\begin{array}{l}\text { HBsAg + } \\
(61 \% \mathrm{HBeAg}+) \\
\text { B } 14 \% \\
\text { C } 81 \% \\
\text { G 3\% }\end{array}$ & $\begin{array}{l}\text { RCT } \\
\mathrm{N}=36 \\
\text { Arms: } \\
\text { 3TC - } 13 \\
\text { TDF- } 12 \\
\text { TDF+3TC - } 11\end{array}$ & Naive & 48 weeks & 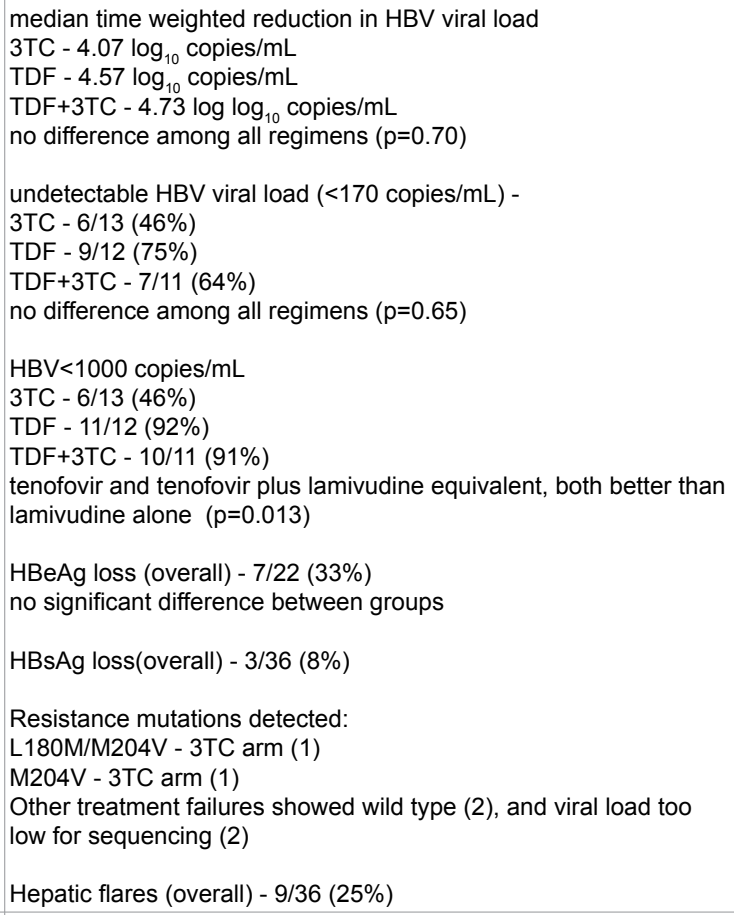 & $\begin{array}{l}\text { Landmark RCT } \\
\text { in treatment } \\
\text { naive patients } \\
\text { showed tenofovir } \\
\text { containing- } \\
\text { regimens are } \\
\text { superior, but only } \\
\text { at an adjusted } \\
\text { higher HBV level } \\
(<1000 \text { copies } / \mathrm{mL} \\
\text { vs. undetectable) }\end{array}$ \\
\hline $\begin{array}{l}\text { Avihingsanon } \\
\text { et al., } 2010 \text { [7] } \\
\text { Thailand }\end{array}$ & $\begin{array}{l}\text { HBsAg+ } \\
(69 \% \mathrm{HBeAg}+) \\
\text { B }-6 \% \\
\text { C }-94 \%\end{array}$ & $\begin{array}{l}\text { RCT } \\
\text { N=16 } \\
\text { Arms: } \\
\text { FTC/ZDV/ } \\
\text { EFV - } 6 \\
\text { FTC/TDF/EFV } \\
-10\end{array}$ & Naive & 48 weeks & $\begin{array}{l}\text { median time weighted area under the curve (TWAUC) reduction in } \\
\text { HBV viral load } \\
\text { FTC/ZDV/EFV - 3.25. } \log _{10} \text { copies/mL } \\
\text { FTC/TDF/EFV - } 5.32 \log _{10} \text { copies/mL } \\
\text { Greater reduction in TWAUC for FTC/TDF/EFV }(p=0.03) \\
\text { undetectable HBV viral load (<170 copies/mL) - } \\
\text { FTC/ZDV/EFV - } 33 \% \\
\text { FTC/TDF/EFV - } 90 \% \\
\text { FTC/TDF/EFV superior to FTC/ZDV/EFV }(p=0.036) \\
\text { HBeAg loss (overall) - } 4 / 11(36 \%) \\
\text { no difference among either regimen } \\
\text { HBsAg loss (overall) - } 1 / 16(6 \%), F T C / Z D V / E F V \text { arm } \\
\text { No resistance data avilable } \\
\text { Hepatic flares (overall) - } 3 / 16(19 \%)\end{array}$ & $\begin{array}{l}\text { Showed FTC/TDF } \\
\text { superior to FTC } \\
\text { alone as HBV- } \\
\text { active agent } \\
\text { Suggested } \\
\text { that FTC with } \\
\text { synergistic activity } \\
\text { to TDF compared } \\
\text { to } 3 T C \text {, hence } \\
\text { the difference in } \\
\text { findings compared } \\
\text { to Matthews et al. } \\
2008 \text { finding }\end{array}$ \\
\hline $\begin{array}{l}\text { Kamdoung et } \\
\text { al., } 2014 \text { [8] } \\
\text { Thailand }\end{array}$ & $\begin{array}{l}\text { HBsAg+ } \\
(63 \% \mathrm{HBeAg}+) \\
\text { B } 17 \% \\
\text { C } 83 \%\end{array}$ & $\begin{array}{l}\text { Prospective } \\
\text { cohort } \\
3 T C \text { as only } \\
\text { active agent } \\
\mathrm{N}=30 \\
\mathrm{HBeAg}+-19 \\
\mathrm{HBeAg}-\mathrm{-} 11\end{array}$ & & $\begin{array}{l}12 \text { months } \\
\text { up to } 5 \\
\text { years }\end{array}$ & $\begin{array}{l}\text { undetectable HBV viral load }\left(<2.18 \log _{10} \mathrm{IU} / \mathrm{mL}, 840 \mathrm{copies} / \mathrm{mL}\right)^{*} \\
12 \text { months } \\
\text { Overall } 20 / 30(67 \%) \\
\text { HBeAg+ }-9 / 19(47 \%) \\
\text { HBeAg- - } 11 / 11(100 \%) \\
\text { Higher suppression in HBeAg- ( } \mathrm{p}=0.004) \\
5 \text { years } \\
\text { Overall } 9 / 30(30 \%) \\
\text { HBeAg+ - } 2 / 19(11 \%) \\
\text { HBeAg- - } 7 / 11 \text { (64\%) } \\
\text { HBeAg loss (overall) - } 37 \% \\
5 \text { years ( } 7 / 19 \text { total; } 7 / 8 \text { virally suppressed with samples at } 5 \text { years) } \\
\text { HBsAg loss (overall) - } 14 \% \text { at } 5 \text { years }(4 / 29 \text { total; } 4 / 17 \text { virally } \\
\text { suppressed with samples at } 5 \text { years) } \\
5 \text {-year cumulative resistance: } 6 / 30(20 \%) \text {, all HBeAg+ } \\
\text { Resistance mutations detected: } \\
\text { M204I (1) } \\
\text { L180M/N173L/M204V(1) } \\
\text { L180M/M204V (2) } \\
\text { L180M/M204I ( } 1) \\
\text { L180M/V173L/M204I (1) } \\
\text { *Some samples diluted by } 10 \text { due to insufficient quantitiy }\end{array}$ & $\begin{array}{l}\text { Showed good } \\
\text { long-term response } \\
\text { for 3TC alone } \\
\text { especially in } \\
\text { HBeAg- patients, } \\
\text { with complete } \\
\text { suppression } \\
\text { in these at } 12 \\
\text { months. Long-term } \\
\text { suppression (5 } \\
\text { years) was } 30 \%\end{array}$ \\
\hline
\end{tabular}




\begin{tabular}{|c|c|c|c|c|c|c|}
\hline $\begin{array}{l}\text { Kim et al., } 2011 \\
{[9]} \\
\text { Kenya }\end{array}$ & $\begin{array}{l}\text { HBsAg+ } \\
(11 \% \text { HBeAg +) } \\
\text { A1 - 100\% }\end{array}$ & $\begin{array}{l}\text { Prospective } \\
\text { cohort } \\
3 \mathrm{TC} \text { as only } \\
\text { active agent } \\
\mathrm{N}=27 \\
\mathrm{HBeAg}+-3 \\
\mathrm{HBeAg}-24\end{array}$ & Naive & 18 months & $\begin{array}{l}\text { undetectable HBV viral load }(<100 \mathrm{IU} / \mathrm{mL}, 560 \text { copies } / \mathrm{mL}) \\
\text { Overall } 89 \%(17 / 19 \text { evaluable patients, with } 5 \text { deaths prior to } 18 \\
\text { months, cause of deaths not reported)HBeAg loss - not reported } \\
\text { HBsAg loss - not reported } \\
\text { Resistance mutations detected: } \\
\text { M204I (1) } \\
\text { A200V/M204I (1) }\end{array}$ & $\begin{array}{l}\text { Showed good } \\
\text { long-term response } \\
\text { for } 3 \text { TC alone } \\
\text { with complete } \\
\text { suppression in } \\
89 \% \text { at } 18 \text { months, } \\
\text { no long term } \\
\text { follow-up }\end{array}$ \\
\hline $\begin{array}{l}\text { Matthews et } \\
\text { al., } 2013[10] \\
\text { Thailand } \\
28.5 \% \\
\text { Australia } \\
40.6 \% \\
\text { USA } 30.9 \%\end{array}$ & $\begin{array}{l}\text { HBsAg+ } \\
(49 \% \text { HBeAg +) } \\
\\
\text { A } 47(50 \%) \\
\text { C } 33(35 \%) \\
\text { All other types } \\
13(14 \%) \\
\text { Not tested } 57\end{array}$ & $\begin{array}{l}\text { Prospective } \\
\text { cohort } \\
\mathrm{N}=165 \\
\text { Thailand } n=47 \\
\text { Australia } n=67 \\
\text { USA } n=51 \\
\\
\text { TDF+FTC/3TC } \\
-94 \text { FTC or } \\
\text { 3TC - 32 } \\
\text { TDF - } 21 \\
\text { No HBV drug } \\
-18\end{array}$ & $\begin{array}{l}\text { HAART- } \\
\text { experienced, } \\
89 \% \text { on HBV- } \\
\text { active regimen }\end{array}$ & 2.8 years & $\begin{array}{l}\text { undetectable HBV viral load (<357 IU } / \mathrm{mL}, 2000 \text { copies } / \mathrm{mL}) \text { at } \\
\text { study visit } \\
\text { Overall } 79.2 \% \text { of study visits } \\
\text { TDF+FTC/3TC - } 86 \% \\
\text { FTC or } 3 \text { TC }-61 \% \text { TDF - } 80 \% \\
\text { No HBV drug - } 53 \% \\
\text { TDF+FTC/3TC associated with higher likelihood of HBV viral } \\
\text { suppression at time of visit than any of the other groups, including } \\
\text { tenofovir monotherapy ( } \mathrm{p}=0.02) \\
\text { HBeAg loss - not reported } \\
\text { HBsAg loss - not reported }\end{array}$ & $\begin{array}{l}\text { Study looking } \\
\text { at treatment- } \\
\text { experienced HIVI } \\
\text { HBV co-infected } \\
\text { patients showing } \\
\text { improved outcomes } \\
\text { with combination } \\
\text { tenofovir therapy }\end{array}$ \\
\hline
\end{tabular}

Legend: HBsAg - hepatitis B surface antigen, HBeAg - hepatitis B e antigen, RCT - randomized controlled trial, 3TC - lamivudine, TDF - tenofovir, AZT - zidovudine, FTC - emtricitabine

Table 1: Selected studies involving HBV/HIV co-infected patients in resource-limited settings.

intention-to-treat analysis. There was no significant difference between any regimen when undetectable HBV viral load $(<170$ copies $/ \mathrm{mL})$ was used as a primary outcome, but the authors found a significant difference when the cutoff for HBV suppression was set at 1,000 copies $/ \mathrm{mL}$. Tenofovir-based regimens were found to be superior to lamivudine alone $(\mathrm{p}=0.013)$, but there was no significant difference between tenofovir alone versus tenofovir plus lamivudine at this cutoff. Thirty-three percent of $\mathrm{HBeAg}$ positive subjects lost $\mathrm{HBeAg}$, and $8 \%$ experienced HBsAg loss over the observation period. Median overall CD 4 count was 36 cells $/ \mu \mathrm{L}$ and increased to 202 cells $/ \mu \mathrm{L}$ at 48 weeks. There was a significantly higher CD4 increase in the tenofovir plus lamivudine arm compared to either lamivudine or tenofovir alone $(+195$ cells $/ \mu \mathrm{L},+141$ cells $/ \mu \mathrm{L},+118$ cells $/ \mu \mathrm{L}$ respectively, $\mathrm{p}=0.048) . \mathrm{HIV}$ viral suppression $(<50$ copies $/ \mathrm{mL})$ was $84 \%$ overall at 48 weeks, with no significant difference between groups.

Avihingsanon and colleagues [7] in a randomized controlled trial looked at HBV responses to patients initiating ARV treatment with an $\mathrm{HBV}$-active component composed of either emtricitabine alone versus a tenofovir plus emtricitabine combination. Sixteen HBsAg positive patients (69\% HBeAg positive) were enrolled with 48 weeks follow-up time. Unlike the Matthews et al. study [6], they found a significantly higher viral suppression rate of HBV with the combination arm with undetectable viral load $(<170$ copies $/ \mathrm{mL})$ as an outcome ( $90 \%$ vs. $33 \%, p=0.036$ ). Median time weighted area under the curve reduction in HBV viral load was greater for tenofovir plus emtricitabine combination compared to emtricitabine alone $(\mathrm{p}=0.03)$. HBeAg loss was $36 \%$ overall with no significant difference between either regimen. HBsAg loss was not reported. The authors suggested that the use of emtricitabine was synergistic with tenofovir as seen in previous in-vitro models, accounting for the superior results compared to tenofovir plus lamivudine in previous studies. They also stated that a tenofovir monotherapy arm would have been helpful to differentiate the effect of tenofovir alone versus combination therapy but this was not incorporated into the study design. CD4 count increases between the emtricitabine $(+120$ cells $/ \mu \mathrm{L})$ and the tenofovir plus emtricitabine group $(+192$ cells $/ \mu \mathrm{L})$ at 48 weeks were not significantly different. HIV viral suppression $(<50$ copies $/ \mathrm{mL}$ ) was not significantly different between either group (FTC alone 83\%; TDF+FTC 100\%).
Khamduang et al. [8] conducted a five-year prospective cohort of $30 \mathrm{HBsAg}$ positive HIV patients in Thailand which evaluated HBV suppression rates defined as less than $150 \mathrm{IU} / \mathrm{mL}$ (840 copies $/ \mathrm{mL}$ ) with lamivudine as the sole HBV agent in the ARV regimen. The higher cutoff was used since some samples were diluted 1:10 due to insufficient volume of sample. They found that all patients who were HBeAg negative $(11 / 30,37 \%)$ successfully suppressed their HBV viral loads, but only $47 \%$ of $\mathrm{HBeAg}$ positive patients successfully suppressed at 12 months, for a total long-term suppression rate of $67 \%$. At the end of the observation period, only nine patients (30\%) had undetectable viral load, composed of seven $\mathrm{HBeAg}$ negative and two $\mathrm{HBeAg}$ positive subjects. Median CD4 count at baseline was 100 cells $/ \mu \mathrm{L}$ and increased to 247 cells $/ \mu \mathrm{L}$ at 12 months and 472 cells $/ \mu \mathrm{L}$ at five years. HIV viral suppression $(<50$ copies $/ \mathrm{mL})$ was achieved in $73 \%$ of patients at 12 months.

A prospective cohort from Kenya by Kim et al. [9] looked at 27 $\mathrm{HBsAg}$ positive HIV patients, the majority of whom were $\mathrm{HBeAg}$ negative $(24 / 27,89 \%)$ and were treated with lamivudine as the sole HBV agent upon initiating ARVs. At 18 months, they had five deaths. The causes of death could not be ascertained. Among the evaluable patients remaining, they found an $89 \%$ undetectable HBV viral load $(17 / 19,89 \%)$ using an in-house RT-PCR with a limit of detection of 10 $\mathrm{IU} / \mathrm{mL}$ (56 copies/mL), and defined HBV suppression as HBV DNA < $100 \mathrm{IU} / \mathrm{mL}$ ( $<560$ copies $/ \mathrm{mL}$ ). CD4 count baseline at was $122 \mathrm{cells} / \mu \mathrm{L}$. No cohort data for HIV viral load or CD4 count was reported at the end of 18 months. Compared to non-HBV co-infected patients $(\mathrm{N}=362)$ HBV-co-infected patients were found to have higher mortality $(21.7 \%$ versus $8.9 \%, \mathrm{p}=0.032$ ).

\section{Treatment-Experienced Studies in RLS}

We reviewed one trial which included a RLS in an ARV treatment-experienced cohort. Matthews et al. [10] conducted a large, multinational cohort study with HBV co-infected, ARV-experienced HIV patients over three countries (Thailand, United States, Australia) with 165 subjects and looked at undetectable HBV DNA as a primary outcome in patient with ARV regimens containing tenofovir plus emtricitabine, lamivudine or emtricitabine, or tenofovir. Only Thailand was an RLS country in this study, and it accounted for $28.5 \%$ of the 
total patients. Patients were followed over a median of 2.8 years. $\mathrm{HBeAg}$ was positive in $49 \%$ of patients. Undetectable HBV DNA was defined as less than $357 \mathrm{IU} / \mathrm{mL}(2000$ copies $/ \mathrm{mL})$ because three different assays were used and this was the lowest common threshold across the assays. Univariate analysis showed that patients from Thailand were less likely to be have detectable HBV DNA (OR 0.22, p=0.04) although this was not significant in multivariate analysis (OR 0.31 , $\mathrm{p}=0.05$ ). Multivariate analysis showed that tenofovir plus emtricitabine or lamivudine was more likely to suppress HBV DNA compared to any kind of monotherapy, including monotherapy with tenofovir alone $(p=0.02)$. The major caveat of this study was that patients were treatment-experienced with lamivudine, and may have had preexisting lamivudine resistance mutations. However, this does not explain the higher HBV viral suppression with combination therapy versus tenofovir alone. Other factors that were found to influence the presence of detectable HBV DNA included less than $95 \%$ adherence to the ARV regimen (even when HIV was undetectable), detectable HIV RNA, presence of $\mathrm{HBeAg}$, duration of $\mathrm{ARV}$ treatment $<2$ years, and CD4 count less than 200 cells/ $\mu \mathrm{L}$.

\section{Recent Treatment Studies In Resource-Rich Settings}

HIV treatment guidelines in the United States and Europe have always recommended the use of dual HBV-active NRTI treatment (tenofovir plus lamivudine/emtricitabine) in treatment-naive patients despite a dearth of evidence for this approach $[11,12]$. A recent metaanalysis and systematic review [13] confirmed the major role of tenofovir in the treatment of $\mathrm{HBV}$ in HIV co-infected patients. The meta-analysis included 23 studies of various designs, including six randomized controlled trials (RCTs) with a total of 550 patients. However only two of the included studies were done in RLS [6,7], and may therefore be less applicable to developing countries due to major epidemiological differences in transmission and genotypes, as well as availability and affordability of antiretrovirals $[4,8]$. The meta-analysis concluded that tenofovir is effective for suppressing HBV to undetectable levels in a majority of HIV and HBV co-infected patients, and that the proportion of patients with suppressed HBV DNA increases over time. This was irrespective of prior lamivudine or emtricitabine treatment. Finally, the authors concluded that the addition of lamivudine or emtricitabine to tenofovir offered no additional benefit, in contrast with established guidelines.

A more recent retrospective cohort study involving $150 \mathrm{HBV}$ coinfected HIV patients in the United States who were followed over 240 weeks showed even more discordant results compared to guideline recommendations. The two arms of the study compared lamivudine as the sole anti-HBV agent versus dual treatment with either tenofovir plus lamivudine or tenofovir plus emtricitabine. There was a trend towards HBV suppression for dual treatment but, overall there was no significant difference in treatment. No patients were treated with tenofovir as the sole anti-HBV agent [14]

\section{HIV-HBV Co-Infection and Disease Progression}

HBV co-infection in HIV-infected patients is associated with decreased HBV clearance as well as an increased risk of progression to chronic hepatitis [1]. Mortality from all causes, as well as liver-related conditions are increased in HBV co-infected HIV patients regardless of the use of ARVs. The impact of HBV on HIV progression is less clearcut, although there is some evidence that is suggestive of decreased ARV response and faster time to development of AIDS [15]. While the progression to HCC may at least be partially due to the prevailing genotype [2], the overall prevalence of HCC in HIV co-infected patients is nearly three-fold increased compared to HIV-seronegative patients [15]. This has become more apparent with increased survival times on ARVs, such that the overall incidence of cirrhosis and HCC has increased in this patient population [4].

HBV genotype is known to affect clinical outcomes and response to treatment [16]. For instance, genotype $\mathrm{C}$ is more likely to be associated with HCC than other genotypes, while genotype A is more likely to be responsive to interferon treatment than other genotypes [2]. Less is known about the interaction of HIV clades with different HBV genotypes, but there is likely an effect because of the variability of progression to AIDS of the different HIV clades [17]. The two treatment-naive studies [8,9] that used lamivudine as the sole active HBV agent showed much higher rates of HBV suppression at one year than most studies with HBV/HIV co-infection treated with lamivudine as a sole agent in developed countries. Genotype A1 was the sole genotype for the Kenyan cohort, while the Thai cohort was mostly made up of genotype $C$ with one genotype B subject [6-9]. While HIV clade $B$ is prevalent for the United States and Europe, the predominant clade for Thailand is CRF01_AE and that for Kenya are clades A and D [17]. While biological responses in the context of these variables may account for some of the observed differences in outcomes of treatment in RLS, the complexities of these interactions and the dearth of studies is such that consistent conclusions on the effect of HIV clades and HBV genotypes on therapeutic outcomes cannot be made at this time.

\section{Hepatitis B Vaccination in HIV-infection}

Vaccination for HBV in HIV-infected patients can be challenging due to the decreased immune response to the vaccine, especially in those with severe immunosuppression [4]. In addition to checking that a patient is negative for $\mathrm{HBsAg}$, an $\mathrm{HBV}$ core antibody (anti-HBc) should be checked to look for occult infection since these occur more frequently in HIV-infected patients [5]. In RLS that are highly endemic for $\mathrm{HBV}$, childhood vaccination with $\mathrm{HBV}$ vaccine is recommended. However, HBV vaccination history may be unreliable and so all HIV patients should be checked for immune status to HBV with an anti-HBs antibody at baseline as well as after vaccination, if possible. The schedule of vaccination in non-HBV immune HIV patients should follow the same three-dose recommendation $(20 \mu \mathrm{g}$ x three doses intramuscularly at zero, one and six months) as HIV-seronegative subjects with a few caveats. In the event that HBsAg and anti-HBs testing reveals non-immune status, even if there is a history and documentation of childhood vaccination to $\mathrm{HBV}$, the initiation of a full course of $\mathrm{HBV}$ vaccination is recommended. In HIV patients with high CD4 counts, vaccination should be given as soon as possible to ensure adequate response before $\mathrm{CD} 4$ counts decline, with documentation of anti-HBs response one to two months after the final dose. In those with CD4 counts below 350 cells $/ \mu \mathrm{L}$, vaccination may be delayed until significant immune reconstitution has occurred on ARVs, weighed against the risk of acquiring de novo $\mathrm{HBV}$ infection while waiting for $\mathrm{CD} 4$ counts to rise. In the event that HBV status and CD4 status cannot be determined due to severe resource constraints, we recommend going ahead with a full course of $\mathrm{HBV}$ vaccination from a public health standpoint, and because the comorbidity of newly-acquired HBV infection in an HIVinfected patient can be considerable.

While there is some evidence that double-dose and intra-dermal administration of HBV vaccine is associated with increased efficacy, more clinical research is needed prior to institution of these alternative modalities. In addition, the utility of giving boosters beyond the original schedule has not been determined, and cannot be routinely recommended at this time [4]. 


\section{Guidelines for Antiviral Therapy for HIV-HBV Co- Infected Patients in RLS}

Looking at the four treatment-naive studies done in RLS, only tenofovir plus emtricitabine showed a convincing superiority over emtricitabine alone, as seen in the Avihingsanon study [7]. There was no difference in tenofovir versus tenofovir plus lamivudine in the Matthews study [6], and even the treatment endpoint had to be increased to show superiority of a tenofovir-based regimen compared to lamivudine. There was no clear effect of improved immunological reconstitution seen with some ARV regimens on HBV clinical outcomes. The last two studies [8,9], both prospective cohorts with lamivudine alone as the HBV-active agent, showed surprisingly high rates of HIV suppression, especially among HBeAg negative patients. These findings suggest that, if available, tenofovir plus emtricitabine is the best option in HBV/ HIV co-infected patients in RLS. However, the benefit of addition of lamivudine to a tenofovir-containing regimen is uncertain since the Matthews study [6] did not show any difference between either arm, and the Avihingsanon [7] study used emtricitabine only.

If tenofovir is in limited supply, $\mathrm{HBeAg}$ testing should be done and lamivudine or emtricitabine as the sole HBV active agent in an ARV regimen can be offered to HBeAg-negative treatment-naive patients for up to five years. HBeAg positive patients should be prioritized to start a tenofovir-containing regimen. While previous studies [18,19] have shown that tenofovir monotherapy is more durable than lamivudine monotherapy for treatment of $\mathrm{HBV}$ in terms of a lower tendency to develop resistance mutations, a negative $\mathrm{HBeAg}$, at least in HIV coinfected patients in RLS, is predictive of more durable suppression rates even with lamivudine monotherapy $[8,9]$.

For lamivudine-experienced HBV/HIV co-infected patients, combination tenofovir plus emtricitabine or lamivudine is the regimen of choice, and is superior to tenofovir monotherapy as shown by the treatment-experienced study by Matthews and her colleagues [10]. This is in contrast with findings of the meta-analysis by Price and his colleagues which concluded that in treatment-experienced patients, there was no benefit to the addition of lamivudine or emtricitabine [13]. Of note, the Matthews study [10] was not included in the Price meta-analysis, nor were any treatment-experienced RLS studies, and therefore this recommendation is new for RLS.

Despite international recommendations to begin ARVs at increasing CD4 counts in RLS, economic considerations result in ARVs being started only in those with low CD4 counts. In these settings, it may be necessary to consider treatment with monotherapy using HBV active agents such as lamivudine, clevudine, entecavir and tenofovir if there is clinically active hepatitis B but the threshold for ARVs have not been reached. This may then adversely impact subsequent ARV regimens and be associated with the emergence of drug resistance, especially in countries where ARV drug repertoires are limited. In the Philippines, where HBV population prevalence is $17 \%$, HIV testing prior to treatment of HBV with NRTI monotherapy is not routine [20]. While historical rates of HIV have been low, it currently has one of the fastest growing HIV epidemics in the world, and haphazard prescription of NRTI monotherapy for HBV infection is not only widespread, but occurs without the benefit of an HIV test [21].

Finally, with regard to occult HBV infection in HIV patients, at least one study done in RLS [22] found high rates of occult HBV infection (10.6\%) in HIV patients and recommended using dual HBV-active treatment for these patients without any prospective evidence for this. However, a more recent prospective study done in the Netherlands (not an RLS) looked at treatment responses of occult HBV viremia to ARV initiation with lamivudine-containing regimens as HBV monotherapy. This study showed that all occult HBV viremia patients with low CD4 counts resolved with ARV treatment [23]. It remains to be seen whether RLS patients will respond in a similar way, and more research is needed to determine whether a combination regime is superior to monotherapy in the case of occult HBV infection.

\section{Conclusions and Recommendations}

In conclusion, treatment of HBV/HIV co-infection in RLS may substantially differ from treatment based on mostly developed-country trials. Tenofovir in combination with emtricitabine has the strongest evidence for efficacy for HBV suppression in RLS, and uncertainties remain about tenofovir monotherapy in ARV treatment-naive patients. Combination treatment with tenofovir plus lamivudine or emtricitabine in treatment-experienced RLS patients is supported by prospective data, in accordance with most published guidelines.

The option of using lamivudine alone as part of the ARV regimen as the initial therapy for co-infected patients who are HBeAg-negative may be preferable for countries who are still struggling with budgetlimitations brought about by a larger ARV rollout as recommended by the most recent WHO guidelines. While there is some evidence for this approach, the data supporting this recommendation remains relatively weak due to the small sizes of the clinical studies performed. Further research needs to be done on the feasibility of this strategy, as other gaps in knowledge, including the treatment of $\mathrm{HBsAg}$ negative occult HBV infection, and country-specific RLS experiences. Nevertheless, the current evidence, while limited is promising, and can be utilized by program managers in RLS while awaiting larger and more comprehensive data.

\section{References}

1. Kourtis AP, Bulterys M, Hu DJ, Jamieson DJ (2012) HIV-HBV coinfection--a global challenge. N Engl J Med 366: 1749-1752.

2. Zhang Q, Cao G (2011) Genotypes, mutations, and viral load of hepatitis $B$ virus and the risk of hepatocellular carcinoma: HBV properties and hepatocarcinogenesis. Hepat Mon 11: 86-91.

3. Nelson PK, Mathers BM, Cowie B, Hagan H, Des Jarlais D, et al. (2011) Global epidemiology of hepatitis $B$ and hepatitis $C$ in people who inject drugs: results of systematic reviews. Lancet 378: 571-583.

4. Sun HY, Sheng WH, Tsai MS1, Lee KY1, Chang SY1, et al. (2014) Hepatitis B virus coinfection in human immunodeficiency virus-infected patients: a review. World J Gastroenterol 20: 14598-14614.

5. Coffin CS, Mulrooney-Cousins PM, Osiowy C, van der Meer F, Nishikawa S, et al. (2014) Virological characteristics of occult hepatitis B virus in a North American cohort of human immunodeficiency virus type 1-positive patients on dual active anti-HBV/HIV therapy. J Clin Virol 60: 347-353.

6. Matthews GV, Avihingsanon A, Lewin SR, Amin J, Rerknimitr R, et al. (2008) $A$ randomized trial of combination hepatitis $B$ therapy in HIV/HBV coinfected antiretroviral naïve individuals in Thailand. Hepatology 48: 1062-1069.

7. Avihingsanon A, Lewin SR, Kerr S, Chang JJ, Piyawat K, et al. (2010) Efficacy of tenofovir disoproxil fumarate/emtricitabine compared with emtricitabine alone in antiretroviral-naive HIV-HBV coinfection in Thailand. Antivir Ther 15: 917-922.

8. Khamduang W, Gaudy-Graffin C, Ngo-Giang-Huong N, Jourdain G, Moreau A, et al. (2012) Long-term hepatitis B virus (HBV) response to lamivudinecontaining highly active antiretroviral therapy in HIV-HBV co-Infected patients in Thailand. PLoS One 7: e42184.

9. Kim HN, Scott J, Cent A, Cook L, Morrow RA, et al. (2011) HBV lamivudine resistance among hepatitis $B$ and HIV coinfected patients starting lamivudine, stavudine and nevirapine in Kenya. J Viral Hepat 18: e447-452.

10. Matthews GV, Seaberg EC, Avihingsanon A, Bowden S, Dore GJ, et al. (2013) 
Citation: Salvana EMT, Salvana AD, Salata RA (2015) HIV with Hepatitis B Co-Infection: Optimizing Treatment in Resource-Limited Settings. J AIDS Clin Res 6: 425. doi:10.4172/2155-6113.1000425

Patterns and causes of suboptimal response to tenofovir-based therapy in individuals coinfected with HIV and hepatitis B virus. Clin Infect Dis 56: e87-94.

11. Panel on Antiretroviral Guidelines for Adults and Adolescents (2014) Guidelines for the use of antiretroviral agents in HIV-1-infected adults and adolescents. Department of Health and Human Services.

12. European AIDS Clinical Society (2014) Guidelines version 7.1 November 2014

13. Price H, Dunn D, Pillay D, Bani-Sadr F, de Vries-Sluijs T, et al. (2013) Suppression of HBV by tenofovir in HBV/HIV coinfected patients: a systematic review and meta-analysis. PLoS One 8: e68152.

14. Kang M, Hollabaugh K, Pham V, Koletar SL, Wu K, et al. (2014) Virologic and serologic outcomes of mono versus dual HBV therapy and characterization of HIV/HBV coinfection in a US cohort. J Acquir Immune Defic Syndr 66: 172-180.

15. Matthews PC, Geretti AM, Goulder PJ, Klenerman P (2014) Epidemiology and impact of HIV coinfection with hepatitis $B$ and hepatitis $C$ viruses in SubSaharan Africa. J Clin Virol 61: 20-33.

16. Franco E, Bagnato B, Marino MG, Meleleo C, Serino L, et al. (2012) Hepatitis $\mathrm{B}$ : Epidemiology and prevention in developing countries. World J Hepatol 4: 74-80.

17. Taylor BS, Sobieszczyk ME, McCutchan FE, Hammer SM (2008) The challenge of HIV-1 subtype diversity. N Engl J Med 358: 1590-1602.
18. Hoff J, Bani-Sadr F, Gassin M, Raffi F (2001) Evaluation of chronic hepatitis $B$ virus (HBV) infection in coinfected patients receiving lamivudine as a component of anti-human immunodeficiency virus regimens. Clin Infect Dis 32: 963-969.

19. Snow-Lampart A, Chappell B, Curtis M, Zhu Y, Myrick F, et al. (2011) No resistance to tenofovir disoproxil fumarate detected after up to 144 weeks of therapy in patients monoinfected with chronic hepatitis B virus. Hepatology 53: 763-773.

20. Wong SN, Ong JP, Labio ME, Cabahug OT, Daez ML, et al. (2013) Hepatitis $\mathrm{B}$ infection among adults in the philippines: A national seroprevalence study. World J Hepatol 5: 214-219.

21. National Epidemiology Center, Department of Health, Republic of the Philippines (2014) Philippine HIV and AIDS registry September 2014.

22. Firnhaber C, Viana R, Reyneke A, Schultze D, Malope B, et al. (2009) Occult hepatitis $B$ virus infection in patients with isolated core antibody and HIV coinfection in an urban clinic in Johannesburg, South Africa. Int J Infect Dis 13 488-492.

23. Cohen Stuart JW, Velema M, Schuurman R, Boucher CA, Hoepelman AI (2009) Occult hepatitis B in persons infected with HIV is associated with low CD4 counts and resolves during antiretroviral therapy. J Med Virol 81: 441-445. 